\title{
Identification of Ruiter's Strains, Isolated from Browned Marinated Herring, as Members of Erwinia herbicola
}

\author{
J. DE SMEDT and J. DE LEY \\ Laboratorium voor Microbiologie en microbiële Genetica, Rijksuniversiteit, B-9000 Gent, Belgium
}

\begin{abstract}
Deoxyribonucleic acid:ribosomal ribonucleic acid hybridizations, determinations of the guanine plus cytosine content of the deoxyribonucleic acid, and numerical analysis of phenotypic features were used to identify Ruiter's strains, isolated from browned marinated herring, as members of Erwinia herbicola.
\end{abstract}

In 1963 Ruiter (15) isolated from cut onions bacteria which caused browning of marinated herring in a marinade factory in the Netherlands. These bacteria were aerobic, oxidase-negative, nonmotile rods which contained catalase, produced acid from glucose, and grew on citrate; they were unable to produce $\mathrm{H}_{2} \mathrm{~S}$ or indole or to reduce nitrate. Ruiter proposed that they probably belonged in Achromobacter anitratum (Schaub and Hauber) Brisou.

Bacterium anitratum was first described by Schaub and Hauber (16) as a group of gramnegative, strictly aerobic, short rods unable to reduce nitrate. They were isolated from clinical material of human source. Brisou (3) placed Bacterium anitratum in the genus Achromobacter for ecological and biological reasons. In 1954 Brisou and Prévot (5) created the genus name Acinetobacter for the nonmotile achromobacters, and Brisou (4) later proposed Acinetobacter anitratum as the type species. This species is now known as Acinetobacter calcoaceticus (1).

The taxonomic position of Ruiter's strains, sometimes named Achromobacter sp., remained uncertain up to now. In the National Collection of Industrial Bacteria catalogue of strains (2) they are listed as unidentified bacteria. We report here on a specific identification of these strains based on numerical analysis of phenotypic features, deoxyribonucleic acid (DNA):ribosomal ribonucleic acid (rRNA) hybridizations, and guanine plus cytosine $(\mathrm{G}+\mathrm{C})$ content of the DNA.

\section{MATERIALS AND METHODS}

Bacterial strains. The organisms used in this study are listed in Table 1. Bergey's Manual of Deter. minative Bacteriology (6) does not give a type strain for Erwinia herbicola. However, Enterobacter agglomerans and Erwinia herbicola were regarded as synonyms by Ewing and Fife (13), who proposed NCTC 9381 as the neotype strain of Enterobacter agglomerans. We included this strain as well as 30 other strains of $E$. herbicola from five different culture collections and from different sources. All of these strains, except G144, formed one tight phenotypic cluster (Fig. 1). Some representative strains of this cluster have been checked in the API $20 \mathrm{E}$ system at $37^{\circ} \mathrm{C}$; the strains were identified by the API computer service as $E$. herbicola, "excellent identification."

Methods. DNA:rRNA hybridizations were carried out as described previously $(9,10,12)$. DNA base compositions, expressed as moles percent $\mathrm{G}+\mathrm{C}$, were determined with a recording thermal spectrophotometer (11). Phenotypic characterization of the strains was effected using the API 20E and API 50 Enterobacteriaceae systems (API System S.A., Montalieu Vercieu, France). For the computer-assisted numerical analysis, the unweighted pair group method was used, with a simple matching coefficient $S_{S M}(17)$.

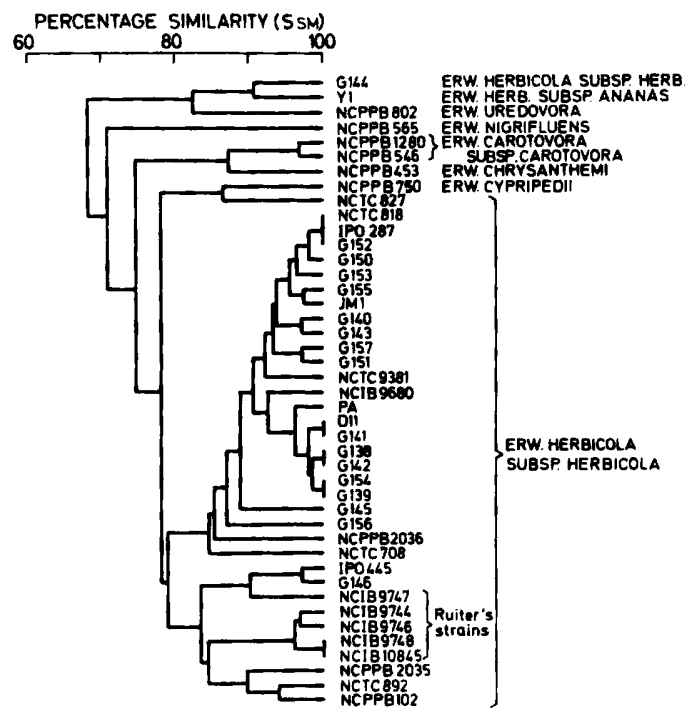

FIG. 1. Dendrogram of simple matching similarity coefficients $\left(\mathrm{S}_{\mathrm{SM}}\right)$, grouped by the unweighted-pair, group-clustering method, showing the relationship of Ruiter's strains with strains of various Erwinia species. 
TABLE 1. List of strains used

\begin{tabular}{|c|c|c|}
\hline $\begin{array}{l}\text { Name according to } \\
\text { Bergey's Manual" }\end{array}$ & Strain no. & Origin $^{b}$ \\
\hline & Ruiter $1=$ NCIB 9744 & $1^{c}$ \\
\hline & Ruiter $3=$ NCIB 9746 & $\mathbf{1}^{\mathrm{c}}$ \\
\hline & Ruiter $4=$ NCIB 9747 & $1^{n}$ \\
\hline & Ruiter $5=$ NCIB 9748 & $2^{d}$ \\
\hline & Ruiter $7=$ NCIB 10845 & $2^{d}$ \\
\hline \multirow[t]{31}{*}{ Erwinia herbicola subsp. herbicola } & D11 & 3 \\
\hline & G 138 & 3 \\
\hline & G 139 & 3 \\
\hline & G 140 & 3 \\
\hline & G 141 & 3 \\
\hline & G 142 & 3 \\
\hline & G 143 & 3 \\
\hline & G 144 & 3 \\
\hline & G 145 & 3 \\
\hline & G 146 & 3 \\
\hline & G 150 & 3 \\
\hline & G 151 & 3 \\
\hline & G 152 & 3 \\
\hline & G 153 & 3 \\
\hline & G 154 & 3 \\
\hline & G 155 & 3 \\
\hline & G 156 & 3 \\
\hline & G 157 & 3 \\
\hline & NCTC 708 & 4 \\
\hline & NCTC 818 & 4 \\
\hline & NCTC 892 & 4 \\
\hline & NCTC 827 & 4 \\
\hline & NCTC 9381 & 4 \\
\hline & PA & 3 \\
\hline & NCIB 9680 & 1 \\
\hline & IPO 287 & 5 \\
\hline & IPO 445 & 5 \\
\hline & NCPPB 2035 & 6 \\
\hline & NCPPB 2036 & 6 \\
\hline & NCPPB 102 & 6 \\
\hline & JM 1 & 3 \\
\hline Erwinia herbicola subsp. ananas & $\mathrm{Y} 1$ & 3 \\
\hline Erwinia uredovora & NCPPB 802 & 6 \\
\hline \multirow[t]{2}{*}{ Erwinia carotovora subsp. carotovora } & NCPPB 1280 & 6 \\
\hline & NCPPB 546 & 6 \\
\hline Erwinia chrysanthemi & NCPPB 453 & 6 \\
\hline Erwinia cypripedii & NCPPB 750 & 6 \\
\hline Erwinia nigrifluens & NCPPB 565 & 6 \\
\hline Erwinia amylovora & NCPPB 683 & 6 \\
\hline Escherichia coli & B & 7 \\
\hline Serratia marcescens & ATCC 10759 & 8 \\
\hline Salmonella typhimurium & 1 & 7 \\
\hline Enterobacter aerogenes & NCTC 10006 & 4 \\
\hline
\end{tabular}

${ }^{a}$ Reference 6.

b 1, National Collection of Industrial Bacteria, Torry Research Station, Aberdeen, Scotland; 2, A. Ruiter, TNO, Ijmuiden, The Netherlands; 3, D. C. Graham, Department of Agriculture and Fisheries, Edinburgh, Scotland; 4, National Collection of Type Cultures, Colindale Avenue, London; 5 , Instituut voor Plantenziektenkundig Onderzoek, Wageningen, The Netherlands; 6, National Collection of Plant Pathogenic Bacteria, Harpenden, Hertfordshire, England; 7, Departmental Collection, Laboratorium voor Microbiologie, Rijksuniversiteit, Gent, Belgium; 8, American Type Culture Collection, Rockville, Md.; 9, International Collection of Phytopathogenic Bacteria, University of California, Davis; 10, Cell Biology Research Institute, Canada Department of Agriculture, Ottawa, Canada.

"Received as "presumably Achromobacter sp."

${ }^{d}$ Received unnamed.

' Renamed Janthinobacterium lividum (10). 
TABLE 1 (continued)

\begin{tabular}{llc}
\hline \multicolumn{1}{c}{$\begin{array}{c}\text { Name according to } \\
\text { Bergey's Manual }\end{array}$} & \multicolumn{1}{c}{ Strain no. } & Origin $^{\text {b }}$ \\
\hline Klebsiella pneumoniae & N4B & 7 \\
Agrobacterium tumefaciens & ICPB TT111 & 9 \\
Pseudomonas fluorescens & ATCC 13525 & 8 \\
Xanthomonas campestris & ICPB T11 & 9 \\
Chromobacterium lividum & NCTC 9796 & 4 \\
Bordetella bronchiseptica & NCTC 8761 & 4 \\
Bacillus subtilis & BQ2 & 7 \\
Arthrobacter globiformis & CBRI 21010 & 10 \\
\hline
\end{tabular}

TABLE 2. Results of DNA:rRNA hybridizations and of $G+C$ determinations ${ }^{a}$

\begin{tabular}{|c|c|c|c|c|}
\hline \multirow[b]{2}{*}{$\begin{array}{l}\text { Organism for DNA } \\
\text { preparation }\end{array}$} & \multirow[b]{2}{*}{ Strain no. } & \multirow{2}{*}{$\begin{array}{c}\mathbf{G}+\mathbf{C} \\
\text { Content } \\
\text { of } \\
\text { DNA } \\
\text { (mol g) })\end{array}$} & \multicolumn{2}{|c|}{ Hybridizations } \\
\hline & & & $T_{m(e)}$ & $\begin{array}{l}\text { Percent } \\
\text { binding }\end{array}$ \\
\hline Escherichia coli & $\mathbf{B}$ & 52.2 & 81 & 0.15 \\
\hline Ruiter's strain & NCIB 9744 & 53.0 & 77 & 0.17 \\
\hline Ruiter's strain & NCIB 9746 & 53.5 & 75.5 & 0.13 \\
\hline Ruiter's strain & NCIB 9747 & 53.7 & $\mathrm{ND}^{c}$ & ND \\
\hline Ruiter's strain & NCIB 9748 & 53.7 & 77 & 0.11 \\
\hline Ruiter's strain & NCIB 10845 & 51.8 & 76 & 0.15 \\
\hline Salmonella typhimurium & 1 & 55.2 & 79 & 0.18 \\
\hline Serratia marcescens & ATCC 10759 & 58.2 & 78 & 0.18 \\
\hline Erwinia amylovora & NCPPB 683 & 54.0 & 76.5 & 0.24 \\
\hline Erwinia herbicola subsp. herbicola & NCTC 9381 & 55.9 & 77 & 0.14 \\
\hline Enterobacter aerogenes & NCTC 10006 & 53.8 & 77 & 0.17 \\
\hline Klebsiella pneumoniae & N4B & 58.6 & 77 & 0.17 \\
\hline Agrobacterium tumefaciens & ICPB TT111 & 60.6 & 63.5 & 0.07 \\
\hline Pseudomonas fluorescens & ATCC 13525 & 60.2 & 64 & 0.09 \\
\hline Xanthomonas campestris & ICPB T11 & 64.3 & 66 & 0.04 \\
\hline Janthinobacterium lividum & NCTC 9796 & 65.5 & 65 & 0.15 \\
\hline Bordetella bronchiseptica & NCTC 8761 & 69.5 & 66 & 0.07 \\
\hline Bacillus subtilis & BQ2 & 47.7 & 58 & 0.16 \\
\hline Arthrobacter globiformis & CBRI 21010 & & 56 & 0.07 \\
\hline
\end{tabular}

a The methods used have been described previously $(9,10,12)$. Hybridizations were performed with ${ }^{14} \mathrm{C}$ labeled rRNA from $E$. coli B.

${ }^{b}$ Percent binding is the amount (micrograms) of rRNA bound to $100 \mu \mathrm{g}$ of DNA.

${ }^{c}$ ND, Not determined.

\section{RESULTS AND DISCUSSION}

The DNA base composition of Ruiter's organisms is 51.8 to $53.7 \mathrm{~mol} \% \mathrm{G}+\mathrm{C}$ (see Table 2). De Ley (7) determined the DNA base composition of a group of numerically analyzed acinetobacters. Acinetobacter anitratum strains constituted a homogeneous group with $\mathrm{G}+\mathrm{C}$ values between 40.7 and $\mathbf{4 2 . 8} \mathrm{mol} \%$. Obviously Ruiter's strains cannot belong in Acinetobacter calcoaceticus (syn.: A. anitratum).

Previously we have shown $(10,12)$ that the similarity between rRNA cistrons, expressed as the midpoint temperature, $T_{m(e)}$, of the thermal elution of the heterologous DNA:rRNA hybrids, appeared to be a good criterion for the identification of organisms and for the classification of taxa at generic and suprageneric levels. Upon hybridization with $\left[{ }^{14} \mathrm{C}\right] \mathrm{rRNA}$ of Escherichia coli B, the rRNA cistrons of Ruiter's strains fell within those of the Enterobacteriaceae. The similarity with the rRNA cistrons of other taxa is much lower (Table 2). The $T_{m(e)}$ of hybrids between DNA of Ruiter's strains and reference rRNA from Agrobacterium tumefaciens is also low (12). We concluded that Ruiter's strains belong in the family Enterobacteriaceae, but the limited resolution of the method used did not allow generic identification.

To pinpoint the exact taxonomic position of Ruiter's strains, we performed a phenotypic characterization using the API $20 \mathrm{E}$ and API 50 Enterobacteriaceae test systems. The tests were carried out at $28^{\circ} \mathrm{C}$ because Ruiter's strains do 
not grow at $37^{\circ} \mathrm{C}$. Thirty-one authentic strains of $E$. herbicola subsp. herbicola, one of $E$. herbicola subsp. ananas, one of $E$. uredovora, one of $E$. nigrifluens, two of $E$. carotovora subsp. carotovora, one of $E$. cypripedii, and one of $E$. chrysanthemi were also included. All of the $E$. herbicola strains and all of Ruiter's strains produced acid from L-arabinose, D-ribose, D-xylose, D-glucose, D-fructose, D-mannose, mannitol, $N$ - acetylglucosamine, maltose, and D-gluconate. None of these strains produced acid from erythritol, L-xylose, methyl-D-xyloside, L-sorbose, dulcitol, inulin, amylose, starch, or glycogen; they did not produce $\mathrm{H}_{2} \mathrm{~S}$, deoxyribonuclease, arginine dihydrolase, lysine decarboxylase, ornithine decarboxylase, oxidase, or gelatinase. The results of the remaining tests are given in Table 3.

TABLE 3. Some phenotypic properties of strains of Erwinia herbicola subsp. herbicola and of Ruiter's strains ${ }^{a}$

\begin{tabular}{|c|c|c|c|c|c|c|}
\hline \multirow{2}{*}{ Character } & \multirow{2}{*}{$\underset{\text { herbicola }^{b}}{\text { Erwinia }}$} & \multicolumn{5}{|c|}{ Ruiter's strains } \\
\hline & & NCIB 9744 & NCIB 9746 & NCIB 9747 & NCIB 9748 & NCIB 10845 \\
\hline \multicolumn{7}{|l|}{ Acid production from: } \\
\hline Glycerol & d & + & + & + & + & + \\
\hline D-Arabinose & d & - & - & + & - & + \\
\hline Adonitol & - & - & - & - & - & - \\
\hline D-Galactose & + & + & + & + & + & + \\
\hline Rhamnose & + & + & + & + & + & + \\
\hline Meso-inositol & + & + & + & + & + & - \\
\hline Sorbitol & d & - & - & - & - & + \\
\hline Methyl-D-mannoside & - & - & - & - & - & - \\
\hline Methyl-D-glucoside & - & - & - & - & - & - \\
\hline Amygdalin & - & + & + & + & + & + \\
\hline Arbutin & + & + & + & + & + & + \\
\hline Salicin & + & + & + & + & + & + \\
\hline D-Cellobiose & $\mathrm{d}$ & + & + & + & + & + \\
\hline Lactose & $d$ & + & + & + & + & + \\
\hline D-Melibiose & d & + & + & + & + & + \\
\hline Sucrose & + & - & - & + & - & - \\
\hline D-Trehalose & + & - & - & + & - & - \\
\hline D-Melezitose & - & - & - & - & - & - \\
\hline D-Raffinose & - & - & - & - & - & - \\
\hline Dextrin & - & - & - & - & - & - \\
\hline Galactarate & d & - & - & + & - & - \\
\hline Use of esculin & $d$ & + & + & + & + & + \\
\hline \multicolumn{7}{|l|}{ Utilization as carbon source: } \\
\hline Malonate & d & + & + & + & + & + \\
\hline Acetate & - & - & - & - & - & - \\
\hline Citrate (Simmons) & d & + & + & + & + & - \\
\hline Citrate (Christensen) & + & + & + & + & + & + \\
\hline \multicolumn{7}{|l|}{ Presence of: } \\
\hline Lipase & d & - & - & - & - & - \\
\hline Tetrathionate reductase & d & + & - & + & - & - \\
\hline$\beta$-Galactosidase & d & + & + & + & + & + \\
\hline Urease & - & - & - & - & - & - \\
\hline Tryptophan deaminase & - & - & - & - & - & - \\
\hline Indole production & - & - & - & - & - & - \\
\hline Acetoin production & + & + & + & + & + & + \\
\hline Methyl red & - & - & - & - & - & - \\
\hline Nitrate reduction & + & - & - & - & - & - \\
\hline
\end{tabular}

${ }^{a}$ Properties were determined in API $20 \mathrm{E}$ and API 50 Enterobacteriaceae tests after $48 \mathrm{~h}$ at $28^{\circ} \mathrm{C} .+$, More than $90 \%$ of the strains were positive; -, more than $90 \%$ of the strains were negative; $d, 11$ to $89 \%$ of the strains were positive.

b Thirty strains; see Fig. 1. 
A numerical analysis of all of the strains tested was carried out using the unweighted pair group clustering method (Fig. 1). On this basis, Ruiter's strains were identified as members of $E$. herbi. cola subsp. herbicola. The known DNA base range of $E$. herbicola extends from 52 to 59 $\mathrm{mol} \% \mathrm{G}+\mathrm{C}(8,18)$; the $\mathrm{G}+\mathrm{C}$ values of Ruiter's strains fall within this range. Many $E$. herbicola strains have been isolated from plant surfaces (14). Ruiter's isolates (15) originated from cut and rotting onions.

\section{ACKNOWLEDGMENTS}

We thank A. Ruiter for the gift of his isolates.

J.D.L. is indebted to the Fonds voor Kollektief Fundamenteel Onderzoek for research and personnel grants. J.D.S. is indebted to the same Fonds for a scholarship.

\section{REPRINT REQUESTS}

Address reprint requests to: Prof. Dr. J. De Ley, Laboratorium voor Microbiology, R.U.G., K.L. Ledeganckstraat 35, B-9000 Gent, Belgium.

\section{LITERATURE CITED}

1. Baumann, P., M. Doudoroff, and R. Y. Stanier. 1968. A study of the Moraxella group. II. Oxidase-negative species (genus Acinetobacter). J. Bacteriol. 95:15201541.

2. Bousfield, I. J., and S. D. Graham. 1975. The National Collection of Industrial Bacteria catalogue of strains, 3rd ed. Her Majesty's Stationery Office, London.

3. Brisou, J. 1953. Essai sur la systématique du genre Achromobacter. Ann. Inst. Pasteur (Paris) 84:812-814.

4. Brisou, J. 1957. Contribution à l'étude de la systématique des Pseudomonadaceae. Ann. Inst. Pasteur (Paris) 93: 397-404.

5. Brisou, J., and A. R. Prévot. 1954. Etudes de systématique bactérienne. Révision des espèces réunies dans le genre Achromobacter. Ann. Inst. Pasteur (Paris) 86: 722-728.
6. Buchanan, R. E., and N. E. Gibbons (ed.). 1974. Bergey's manual of determinative bacteriology, 8 th ed. The Williams \& Wilkins Co., Baltimore.

7. De Ley, J. 1968. DNA base composition and taxonomy of some Acinetobacter strains. Antonie van Leeuwenhoek J. Microbiol. Serol. 34:109-114.

8. De Ley, J. 1968. DNA base composition of yellow Erwinia strains. Antonie van Leeuwenhoek J. Microbiol. Serol. 34:257-262.

9. De Ley, J., and J. De Smedt. 1975. Improvements of the membrane filter method for DNA:rRNA hybridization. Antonie van Leeuwenhoek J. Microbiol. Serol. 41:287-307.

10. De Ley, J., P. Segers, and M. Gillis. 1978. Intra- and intergeneric similarities of Chromobacterium and Janthinobacterium ribosomal ribonucleic acid cistrons. Int. J. Syst. Bacteriol. 28:154-168.

11. De Ley, J., and J. Van Muylem. 1963. Some applications of deoxyribonucleic acid base composition in bacterial taxonomy. Antonie van Leeuwenhoek J. Microbiol. Serol. 29:344-358.

12. De Smedt, J., and J. De Ley. 1977. Intra- and intergeneric similarities of Agrobacterium ribosomal ribonucleic acid cistrons. Int. J. Syst. Bacteriol. 22:222-240.

13. Ewing, W. H., and M. A. Fife. 1972. Enterobacter agglomerans (Beijerinck) comb. nov. (the herbicola-lathyri bacteria). Int. J. Syst. Bacteriol. 22:4-11.

14. Lelliott, R. A. 1974. Genus XII. Erwinia Winslow, Broadhurst, Buchanan, Krumwiede, Rogers and Smith 1920, 209, p. 332-339. In R. E. Buchanan and N. E. Gibbons (ed.), Bergey's manual of determinative bacteriology, 8th ed. The Williams \& Wilkins Co., Baltimore.

15. Ruiter, A. 1963. Ueber eine braune Verfärbung von mariniertem Hering. Dtsch. Lebensm. Rundsch. 4:110-111.

16. Schaub, I. G., and F. D. Hauber. 1948. A biochemical and serological study of a group of identical unidentifiable gram-negative bacilli from human sources. J. Bacteriol. 56:379-385.

17. Sokal, R. R., and C. D. Michener. 1958. A statistical method for evaluating systematic relationships. Univ. Kansas Sci. Bull. 38:1409-1438.

18. Starr, M. P., and M. Mandel. 1969. DNA base composition and taxonomy of phytopathogenic and other Enterobacteria. J. Gen. Microbiol. 56:113-123. 